\title{
Pentosenucleic Acid (PNA) Content, Cytoplasmic Basophilia, and Premortal Enlargement of Mitochondria of Mammalian Liver Cells
}

\author{
Atuhiro Sibatani ${ }^{2}$ and Michio Fukuda ${ }^{3}$ \\ Microbial Diseases Research Institute, University of Osaka, Osaka, Japan
}

Receired September 15, 1953

\section{Introduction}

Ordinary mammalin livers are rich in PNA, which gives rise to the prominent basophilia of hepatic cytoplasm. The pattern of basophilia of the hepatic cytoplasm is subject to considerable modification according to the metabolic activity of animals, and this may reflect the change in PNA content of the liver. However, Farber, Koch-Weser, Szanto, and Popper (1951) have shown that the apparent reduction of cytoplasmic basophilia of liver cells is not necessarily accompanied by a corresponding decrease in PNA content per liver as established chemically. Furthermore, there is much discussion about the validity of interpreting histochemical data even in semiquantitative sense (Glick, Engstrom, and Malmstrom, 1951). A part of PNA of cells may be occuluded by proteins bound to it and fail to react basophilically (Kaufmann, McDonald, and Gay, 1948; Alfert, 1952). The concentration of PNA in cells may change appreciably even if the quantity of PNA present in a single cell is retained at a constant level, owing to the considerable modification of the cell volume which is due to the change in quantity of other major cell constituents such as water, glycogen, lipids, and proteins. There is also much uncertainty about the reliability of various attempts to estimate the total amount of PNA in a single cell by use of microspectrophotometry.

Under these circumstances it may be desirable to examine the relation between basophilic pattern and PNA content of the cell. Some distinct types of cytoplasmic basophilia of mammalian liver cells have been described in a previous report (Sibatani, 1949). Among these types, the one appearing in the agonal state resulting from starvation has attracted the special attention of the senior author. This type is characterized by a prominent enlargement of mitochondria. The cytoplasmic basophilia of this type appears as the negative picture of mitochondria, forming a rim around spherical, clear central

1 Aided by the Scientific Research Fund of the Ministry of Education given to the Synthetic Research Groups on "Nucleic Acids".

2 Present adress: Dejartment of Cytochemistry and Department of Histology, Yamaguti Medical School, Nakaube, Ube, Yarraguti-ken, Japan.

3 Present adress: 2705, Sinmatidôri 2-tyôme, Tkeda, Osaka-hu, Japan. 
space which corresponds the enlarged mitochondria (Sibatani, 1950). Experiments have now been extended to other examples causing similar pictures, and the results of chemical analysis for nucleic acids and proteins, conducted in cell unit, have been correlated with morphological observations made on the same material.

\section{Materials and methods}

Animals:- The majority of animals used in this investigation served as materials in other experiments which were reported in previous papers (Fukuda and Sibatani, $1953 \mathrm{a}-\mathrm{c}$ ). These comprise normal young and adult rats, adult rats dying from prolonged starvation, young rats whose growth had been suppressed severely by restricted caloric intake, and normal and scurvy-dying guinea pigs. In addition, control mice and mice dying from injection of Shigella dysenteriae exotoxin (Hosoya, 1943) were studied. In this experiment, male mice of $12 \mathrm{~g}$ body weight were employed. Each experimental mouse received a single dose of $10 \mu \mathrm{g}$ purified exotoxin through intarvenous injection. In about 30 hours after the injection, animals began to suffer from diarrhea and in $41-43$ hours they became moribund. Biopsy materials were taken at this stage and subjected to biochemical and cytological observations.

Biochemical:-Nucleic acids phosphorus and protein nitrogen were determined as in previous papers (Fukuda and Sibatani, $1953 \mathrm{~b}, \mathrm{c}$ ); they were expressed in terms of quantity per cell or per liver as well as per $100 \mathrm{~g}$ liver, the method of calculation being the same as reported before (Fukuda and Sibatani, 1953 b).

Cytological:-PNA of the liver cell was stained with thionin after fixing with formalin. Mitochondria were demonstrated through Regaud's fixation and staining with iron hematoxylin. The procedures were the same as employed before (Sibatani, 1950). The biochemical and morphologic studies were made on the representative samples of the same livers.

\section{Results}

Within the range of physiologic change in the cytoplasmic basophilia of hepatic cells, three major types of the basophilic pattern may be distinguished. The first, standard type (type I) is found in the liver of normal, well-nourished animals, characterized by the heterogeneous distribution of PNA which forms irregular clumps packed rather compactly in not so large cytoplasm (normal type of Sibatani, 1949). This type may show moderate quantity of glycogen in the cytoplasm. The second, glycogen-deficient type (type II) may be found in the liver of animals administered protein-deficient diet or subjected to undernourishment by restricting caloric intake, especially after the temporary withdrawal of food. This type is characterized by the homogeneous distribution of PNA (reacting type of Sibatani, 1949). The third, glycogen-rich type (type III) is found shortly after the food intake of fasted, protein-deficient 
or caloric-restricted animals. The PNA is sparsely distributed in the large, rarefied cytoplasm, the bulk of which is occupied by glycogenic material (recovering type of Sibatani, 1949).

When stained with basic dyes, the difference in basophilic pattern of hepatic cytoplasm among these three types appears to be quite conspicuous. This fact may lead to an idea that the PNA of liver cytoplasm would have some important significance in the change of the functional state of liver cells as revealed by such different types of basophilic pattern; and one may suspect whether some quantitative change in PNA content of the liver cell might be correlated to the appearance of such types.

Young litter rats weighing about $40 \mathrm{~g}$ were undernourished by restricting caloric intake so as to keep their body weights below $50 \mathrm{~g}$ during the period of 4 weeks (Fukuda and Sibatani, $1953 \mathrm{a}, \mathrm{b}$ ). Livers of three animals taken from this groups now showed the above-mentioned three types (Figs. 1-3). Biochemical analysis (Table 1) revealed that the quantity of PNA-P per $100 \mathrm{~g}$ liver (referred to PNA concentration below) is much lower in the type III liver (Fig. 3) than the other two livers representing types I and II respectively

Table 1. PNA and protein contents of the average liver cells of young rats the growth of which has been retarded by restricting caloric intake

\begin{tabular}{|c|c|c|c|c|c|c|c|c|c|c|}
\hline \multirow{2}{*}{$\begin{array}{c}\text { Animal } \\
\text { No. }\end{array}$} & \multirow{2}{*}{$\begin{array}{c}\text { Final } \\
\text { body } \\
\text { weight }\end{array}$} & \multirow{2}{*}{$\begin{array}{c}\text { Period } \\
\text { of } \\
\text { expt. }\end{array}$} & \multicolumn{3}{|c|}{ Quantity per cell } & \multicolumn{2}{|c|}{$\begin{array}{l}\text { Quantity per } \\
100 \mathrm{~g} \text { liver }\end{array}$} & \multirow{2}{*}{$\frac{\text { PNA- }}{P}-\frac{\text { DNA- }}{P}$} & \multirow{2}{*}{$\frac{\text { PNA-P }}{\text { protein }} \frac{N}{N}$} & \multirow{2}{*}{$\begin{array}{c}\text { Type of } \\
\text { basophilia }\end{array}$} \\
\hline & & & mass & PNA & $\begin{array}{c}\text { protein- } \\
\mathrm{N}\end{array}$ & $\stackrel{\text { PNA- }}{\mathrm{P}}$ & $\begin{array}{c}\text { protein- } \\
\mathrm{N}\end{array}$ & & & \\
\hline & $g$ & $d a y$ & $\mu \mu g$ & $\mu \mu g$ & $\mu \mu g$ & $m g$ & $g$ & & & \\
\hline $\begin{array}{c}1 \\
\text { (Fig. 1) }\end{array}$ & 51 & 28 & 2770 & 22.5 & 62.5 & 80.3 & 2.26 & 2.43 & 0.036 & I: standard \\
\hline$\stackrel{2}{\text { (Fig. 2) }}$ & 51 & 30 & 2820 & 23.8 & 67.2 & 83.5 & 2.38 & 2.51 & 0.035 & $\begin{array}{l}\text { II : glyco- } \\
\text { gen-dericient }\end{array}$ \\
\hline $\begin{array}{c}3 \\
\text { (Fig. } 3 \text { ) }\end{array}$ & 49 & 26 & 3160 & 23.4 & 61.8 & 73.2 & 1.46 & 2.52 & 0.037 & $\begin{array}{l}\text { III : glyco- } \\
\text { gen-rich }\end{array}$ \\
\hline Control* & 50 & - & 3900 & 33.9 & 75.0 & 85.6 & 1.93 & 3.68 & 0.044 & I: standard \\
\hline
\end{tabular}

* Mean of 6 animals.

(Figs. 1 and 2), while the quantity of PNA per average liver cell ${ }^{1}$ (referred to PNA per cell) is quite similar in all of these livers.

This fact shows that a certain difference in the basophilic pattern of hepatic cytoplasm may rest upon the change in PNA concentration, but it does not imply the change in PNA per cell. It should be noted that the average cell mass, which was calculated as in a previous communication (Fukuda and Sibatani, $1953 \mathrm{~b}$ ), is heighest in glycogen-rich type III. The

1 It should be pointed out that the error in calculating PNA and mass per average hepatic cell. caused by the presence of 35 per cent non-parenchymal nuclei in the total nuclear population of rat liver, may not be serious, if this is taken to represent a relative value, for PNA of the liver is overwhelmingly confined to parenchymal cells and the volume of the parenchymal cell usually amounts to 90 per cent of the whole tissue volume (Fukuda and Sibatani, $1953 \mathrm{~b}$ ). 
fact that the concentration of protein- $\mathrm{N}$ is lowest in this type is apparently a reflexion of the richness in glycogen content of the hepatic cell.

In all of the above three types the size of mitochondria is small, regardless of their shape and distribution in the cytoplasm. In contrast to this, large mitochondria are consistently found in the forth type of hepatic basophilia, the "catastrophic" or agonal type, which is encountered in animals dying or having died of starvation and some other causes (Sibatani, 1949). In this type the entire cytoplasm takes a foam-like structure, the PNA being localized around the large, spherical mitochondria which do not stain with basic dyes

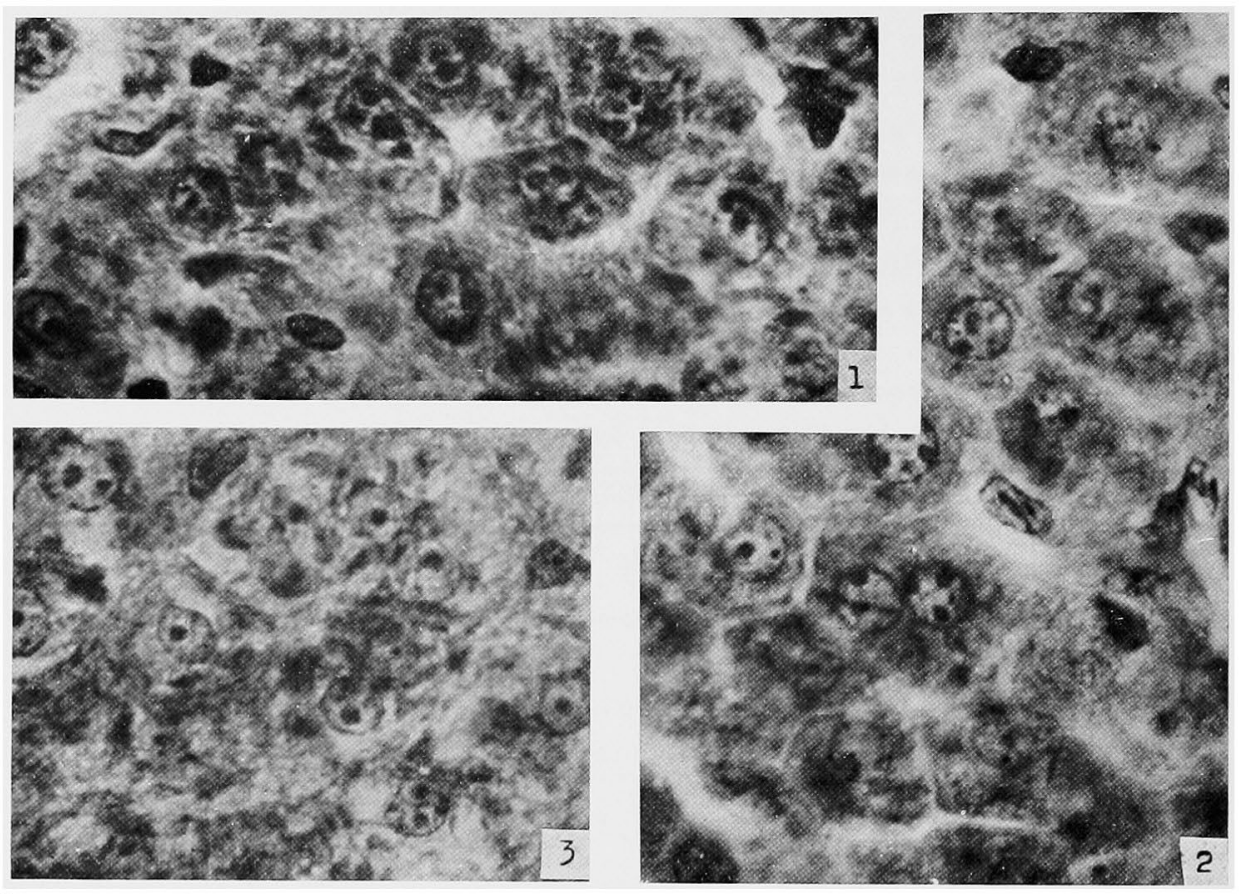

Figs. 1-3. Livers of young rats the growth of which was severely delayed by restricting caloric intake for 4 weeks. See Table 1 for biochemical analysis. Thionin staining. $\times 1100:$ 1, Animal No. 1. Standard type (type I). 2, Animal No. 2. Glycogen-deficient type (type II.) 3, Animal No. 3. Glycogen-rich type (type III).

and appear as clear central spaces encircled with basophilic rim.

Table 2 shows the biochemical analysis on the liver of three rats (initial body weight: about $200 \mathrm{~g}$ ) dying of prolonged starvation. Out of these, the rat No. 6 failed to show the enlarged mitochondria of the liver cell. This may be ascribed to the premature killing of the animal because the enlargement of mitochondria takes place only just before the fatal death of the animal. This inference is supported by the short period of fasting, heigher values of cell mass and of PNA and protein- $\mathrm{N}$ per cell of this particular instance than those of the other two cases which showed enlarged mitochondria (Animals No. 4 and 5). Although these two animals showed a marked de- 
crease in PNA as well as protein-N per liver, we cannot conclude from this fact only that the decrease in PNA of liver cell directly induces the appearance of "catastrophic" type of hepatic basophilia. It should be added that the concentration of protein- $\mathrm{N}$ of this type does not differ markedly from that of the control or type I liver. DNA per liver or per cell does not show any

Table 2. PNA and protein contents of the average liver cells of male adult rats dying of prolonged starvation

\begin{tabular}{|c|c|c|c|c|c|c|c|c|c|c|c|}
\hline \multirow{2}{*}{$\begin{array}{c}\text { Animal } \\
\text { No. }\end{array}$} & \multirow{2}{*}{$\begin{array}{c}\text { Initial } \\
\text { body } \\
\text { weight }\end{array}$} & \multirow{2}{*}{$\begin{array}{l}\text { Per cent } \\
\text { loss of } \\
\text { body } \\
\text { weight }\end{array}$} & \multirow{2}{*}{$\begin{array}{c}\text { Period } \\
\text { of } \\
\text { expt. }\end{array}$} & \multicolumn{3}{|c|}{ Quantity per cell } & \multicolumn{2}{|c|}{$\begin{array}{l}\text { Quantity per } \\
100 \mathrm{~g} \text { liver }\end{array}$} & \multirow{2}{*}{$\begin{array}{l}\text { PNA- } \\
\frac{P}{\mathrm{PNA}-} \\
\mathrm{P}\end{array}$} & \multirow{2}{*}{ 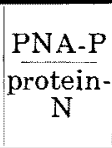 } & \multirow{2}{*}{$\begin{array}{c}\text { Premortal } \\
\text { enlargement } \\
\text { of } \\
\text { mito- } \\
\text { chondria }\end{array}$} \\
\hline & & & & mass & PNA & $\begin{array}{l}\text { Protein- } \\
\mathrm{N}\end{array}$ & $\underset{\mathrm{P}}{\mathrm{PN}}$ & ${ }_{N}^{\text {protein- }}$ & & & \\
\hline & $g$ & & $d a y$ & $\mu \mu g$ & $\mu \mu g$ & $\mu \mu g$ & $m g$ & $g$ & & & \\
\hline 4 & 200 & 33 & 9 & 2720 & 12.2 & 60.5 & 44.6 & 2.21 & 1.04 & 0.020 & + \\
\hline 5 & 210 & 38 & 11 & 2770 & 14.2 & 55.3 & 50.8 & 2.00 & 1.35 & 0.025 & + \\
\hline 6 & 190 & 32 & 7 & 3410 & 27.4 & 79.6 & 79.6 & 2.33 & 2.40 & 0.034 & - \\
\hline Control & 200 & - & - & 6370 & 52.5 & 150 & 81.5 & 2.35 & 4.59 & 0.034 & - \\
\hline
\end{tabular}

* Mean of 3 male animals.

Table 3. PNA and protein contents of the average liver cells of guinea pigs in experimental ascorbic acid deficiency

\begin{tabular}{|c|c|c|c|c|c|c|c|c|c|c|}
\hline \multirow{2}{*}{$\underset{\text { No. }}{\operatorname{Animal}}$} & \multirow{2}{*}{$\begin{array}{c}\text { Initial } \\
\text { body } \\
\text { weight }\end{array}$} & \multirow{2}{*}{$\begin{array}{c}\text { Per cent } \\
\text { loss of } \\
\text { body } \\
\text { wt. }\end{array}$} & \multicolumn{3}{|c|}{ Quantity per cell } & \multicolumn{2}{|c|}{$\begin{array}{l}\text { Quantity per } \\
100 \mathrm{~g} \text { liver }\end{array}$} & \multirow{2}{*}{$\begin{array}{l}\text { PNA- } \\
\frac{\mathrm{P}}{\mathrm{DNA}}-\end{array}$} & \multirow{2}{*}{ 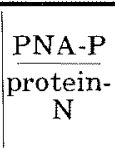 } & \multirow{2}{*}{$\begin{array}{c}\text { Premortal } \\
\text { enlarge- } \\
\text { ment of } \\
\text { mito- } \\
\text { chondria } \\
\end{array}$} \\
\hline & & & mass & PNA & $\begin{array}{c}\text { protein- } \\
\mathrm{N}\end{array}$ & $\stackrel{\mathrm{PNA}}{\mathrm{P}}$ & $\begin{array}{l}\text { protein- } \\
\mathrm{N}\end{array}$ & & & \\
\hline Control & $g$ & & $\mu \mu g$ & $\mu \mu g$ & $\mu \mu g$ & $m g$ & $g$ & & & \\
\hline (Fig. $\left.{ }^{7}-5\right)$ & 290 & 0 & 3090 & 20.4 & 69.2 & 65.4 & 2.24 & 2.26 & 0.029 & - \\
\hline 8 & 285 & 0 & 3460 & 22.0 & 85.4 & 63.2 & 2.47 & 2.45 & 0.026 & - \\
\hline 9 & 300 & 0 & 3540 & 21.6 & 81.6 & 60.2 & 2.30 & 2.39 & 0.026 & - \\
\hline $\begin{array}{l}\text { Scorbutic } \\
10 \\
\text { (Fig. } 6-7 \text { ) }\end{array}$ & 290 & 24 & 3250 & 22.6 & 72.6 & 68.6 & 2.23 & 2.47 & 0.031 & \pm \\
\hline 11 & 290 & 24 & 2730 & 19.5 & 50.1 & 70.7 & 1.84 & 2.15 & 0.039 & + \\
\hline $\begin{array}{c}12 \\
\text { (Fig. 8-9) }\end{array}$ & 290 & 31 & 2710 & 22.1 & 57.4 & 80.8 & 2.12 & 2.42 & 0.038 & + \\
\hline
\end{tabular}

significant change in rats dying of prolonged starvation or ascorbic acid deficiency which is mentioned below (Fukuda and Sibatani, 1953a, b, c). This fact clearly indicates that there is no change in cell number of the liver undergoing the premortal enlargement of mitochondria.

One of the typical examples of the premortal enlargement of mitochondria is represented by the liver of scurvy-dying guinea pigs. Bourne (1951) already pointed out that mitochondria clump together and coalese to form a enlarged sphere in scurvy. The mechanism suggested is the same as the one presented 

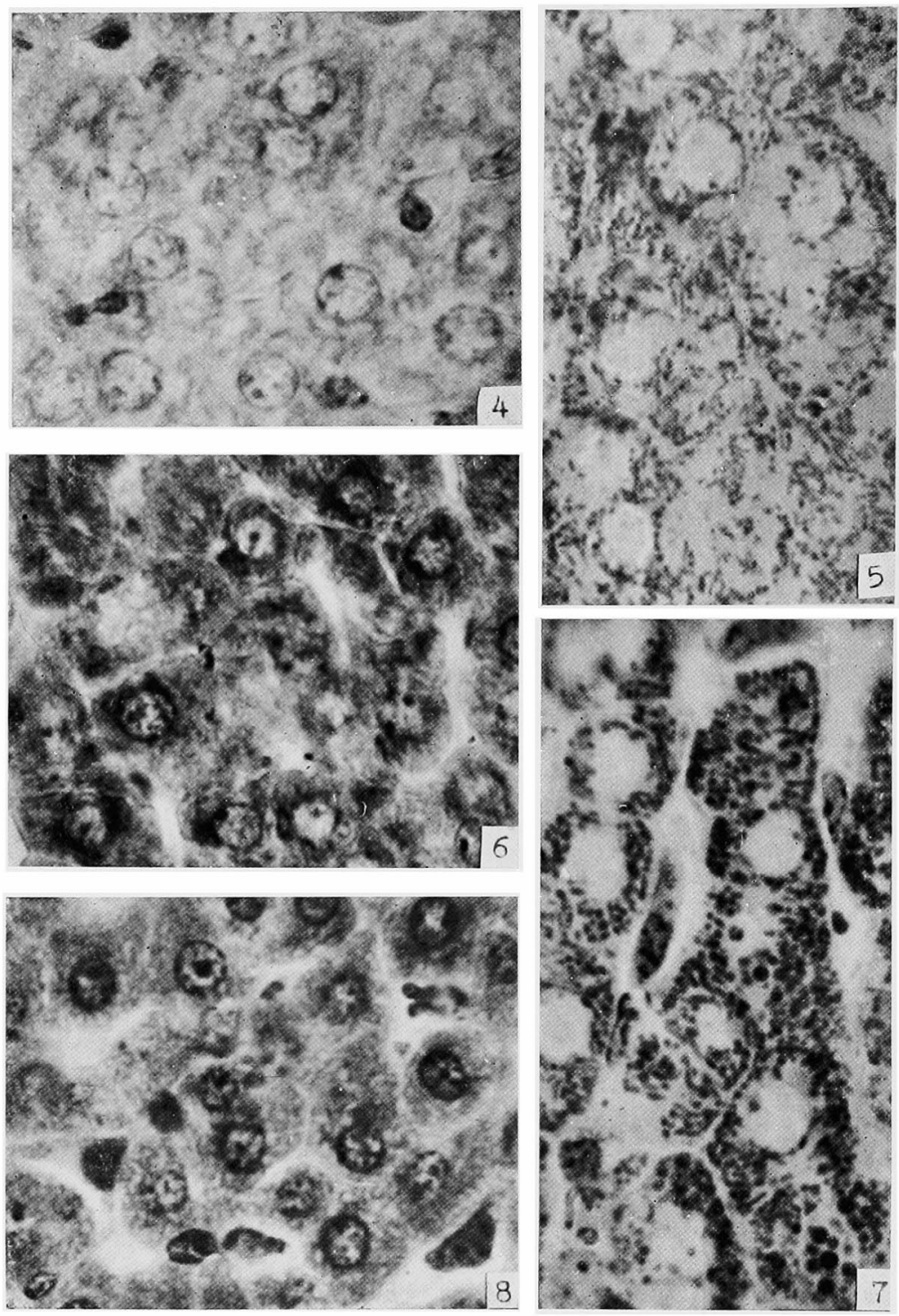

Figs. 4-8. 4, Liver of control guinea pig (Animal No. 7). Glycogenrich type. Thionin. Note the large eytoplasm. 5, The same. Fine rod-like and granular mitochondria stained with iron hematoxylin. 6 , Liver of guinea pig dying of scurvy (Animal No. 10). Intermediate between glycogen-deficient and "eatastrophic" types. Thionin. Moderately enlarged mitochondria are to be recognized as a negative figure. Cells are shrunken. 7, The same. Iron hematoxylin. Moderately enlarged mitochondria are rod-like or granular. Those at the lower right are of large spherical shape. 8, Liver of guinea pig dying of scurvy; another instance (Animal No. 12). "Catastrophic" type. Thionin. Typically enlarged mitochondriat are seen in shrunken cells, resulting in a foam-like structure of hepatic cytoplasm: $\times 1100$. See Table 3 for biochemical analysis. by Sibatani (1949) in the instances of premortal enlargement of mitochondria caused by starvation. If sacrificed at sufficiently advanced stage of agony, scorbutic

guinea pig livers show a basophilic pattern typical of "catastrophic" type (Animals No. 11 and 12, Figs. 8 and 9). Animal No. 10 was premautre in this respect (Figs. 6 and 7). Table 3 shows that the protein- $\mathrm{N}$ per cell of scorbutic livers with typically enlarged mitochondria (No. 11 and 12) is significantly lower than the control livers (No. 79; Figs. 4-5), while PNA 
per cell is quite similar in both scorbutic and normal livers. It should thus be concluded that the premortal enlargement of mitochondria may appear without a decrease in PNA per cell, but decrease in protein- $N$ per cell seems to accompany this change.

In addition, it may be of interest to notice that the PNA concentration of the normal guinea pig liver is lower than those of scorbutic guinea pig (Table 3) and normal rat (Table 2) livers. This explains the weak basophilia of control guinea pig liver (Figs. 4 and 5),

In starvation, scurvy, and some other cases, the premortal mitochondrial enlargement appears evenly all over the liver tissue. Though not typical in this respect, a similar picture was observed in mice dying from injection of Shigella dysenteriae exotoxin. Among 3 dysentery-dying mice examined, Animal No. 18 did not show significant change in liver morphology probably because of premature killing of the animal. No. 16 and 17 livers showed mitochondrial enlargement only in peripheral halves of hepatic lobules. Many

Table 4. PNA and DNA contents of livers of male mice (12 g) treated with exotoxin of Shigella dysenteriae

\begin{tabular}{|c|c|c|c|c|c|c|}
\hline \multirow{2}{*}{ Animal No. } & \multicolumn{2}{|c|}{ PNA-P } & \multicolumn{2}{|c|}{ DNA-P } & \multirow{2}{*}{$\frac{\text { PNA-P }}{\text { DNA-P }}$} & \multirow{2}{*}{$\begin{array}{l}\text { Premortal } \\
\text { enlargement } \\
\text { of } \\
\text { mitochondria }\end{array}$} \\
\hline & per liver & per $100 \mathrm{~g}$ liver & par liver & per $100 \mathrm{~g}$ liver & & \\
\hline Control & $\mu g$ & $m g$ & $\mu g$ & $m g$ & & \\
\hline $\begin{array}{c}13 \\
\text { (Fig. 14) }\end{array}$ & 789 & 93.6 & 218 & 27.2 & 3.62 & - \\
\hline 14 & 756 & 108 & 196 & 28.0 & 3.86 & - \\
\hline 15 & 833 & 104 & 232 & 29.0 & 3.58 & - \\
\hline Mean & 793 & 104 & 215 & 28.1 & 3.69 & \\
\hline \multicolumn{7}{|l|}{ Exotoxin } \\
\hline $\begin{array}{c}16 \\
\text { (Figs. 15-16) }\end{array}$ & 568 & 94.7 & 220 & 36.6 & 2.53 & + \\
\hline $\begin{array}{c}17 \\
\text { (Figs. 10-13) }\end{array}$ & 394 & 65.7 & 215 & 35.9 & 1.83 & + \\
\hline 18 & 565 & 94.2 & 223 & 37.5 & 2.51 & - \\
\hline Mean & 509 & 84.9 & 220 & 36.6 & 2.31 & \\
\hline
\end{tabular}

of the cells containing enlarged mitochondria are markedly shrunken, and strongly basophilic (Figs. 15 and 16). No sign of necrosis of hepatic cells and of cellular infiltration was found. In agreement with this biochemical analysis of nucleic acids revealed that DNA per liver of dysentery exotoxindying mice did not change from that of control mice. Both PNA/DNA (relative value of PNA per cell) and PNA concentration were decreased significantly from the normal level. The strong basophilia of the perilobular shrunken cells might lead to postulating high PNA content of these cells, but at the same time the diminished volume of the cell must be taken into account. Considering the greatly decreased PNA/DNA of the total liver, 


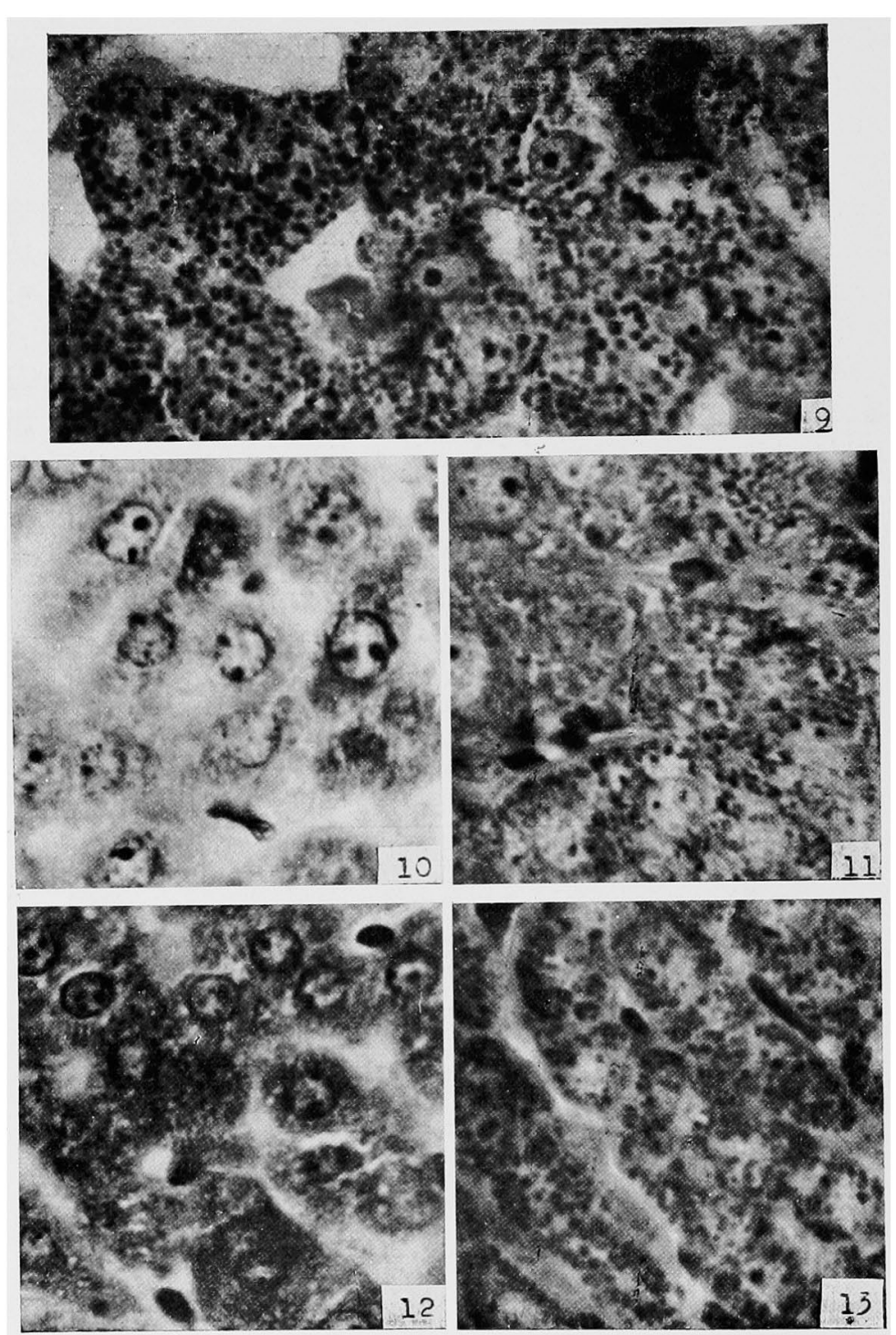

Figs. 9-13. 9, Scurvy-dying liver. Iron hematoxylin. The same liver as given in Fig. 8 (Animal No. 12). Typically enlarged mitochondria. See Table 3 for biochemical analysis. 10-13, Livers of mouse dying from injection of dysentery exotoxin (Animal No. 17). Biochemical analysis are listed in Table 4: 10, Thionin. Central part of the lobule; weak basophilia. 11, The same. Iron hematoxplin. Mitochondria are not enlarged and rather ill-defined. 12, Thionin. Peripheral part of the lobule; foam-like structure of shrunken cytoplasm which is densely basophilic. 13, The same. Iron hematoxylin, showing enlarged mitochondria: $\times 1100$. this local high concentration of PNA does not seem to mean an increased PNA per cell even in these particular cells. The cells in central half of the hepatic lobule (Figs. 10 and 11) look somewhat like normal liver cells (Fig. 16), but they are rather diminished in size and often also in basophilia. The PNA/DNA of the almost normal No. 18 liver is similar to that of morphologically afected No. 16 liver. This fact again suggests that the decrease in PNA per cell is not responsible for the premortal enlargement of mitochondria.

\section{Discussion}

In this report instances of liver injuries which bring about the premortal enlargement of mitochondria were extended to deaths caused by experimental 
scurvy and by dysentery extoxin. Although detailed investigation has not been performed, similar pictures were obtained in some other cases such as guinea pigs which died from infection of Spirillum minus (rat-bite fever). However, there are a good many kinds of diseases which kill animals with severe liver damages that may result in a focal or over-all necrosis or a fatty degeneration without showing marked enlargement of mito-
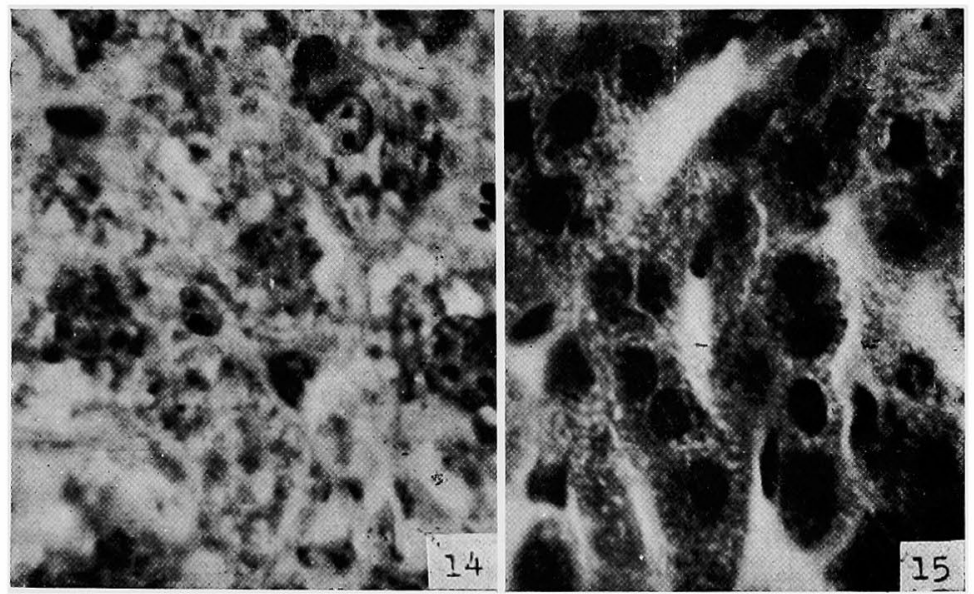
chondria at the agonal stage. As to the pathological change caused by bacterial endotoxin, necrotic degeneration of the liver parenchyma is reported (Homma, Katsura, Hosoya, Miyazaki, Kimura, and Saito, 1951). Appearance of such a change is unprofitable for biochemical analysis, because

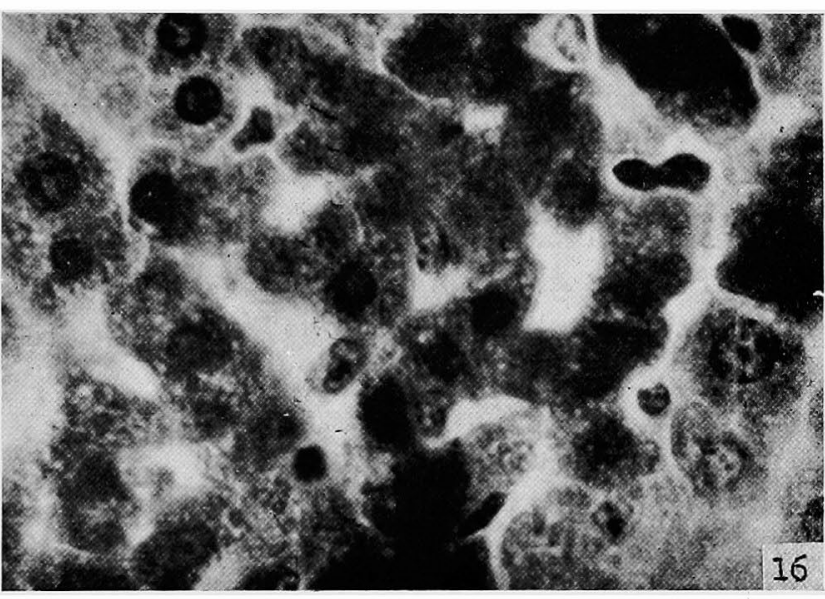

Figs. 14-16. 14, Liver of control mouse (Animal No. 13). Standard type, but not typical. Thionin. 15, Liver of dysentery exotoxindying mouse; another instance (Animal No. 16). Thionin. Strongly shrunken cells with densely basophilic, foam-like eytoplasm. 16, The same. The degree of basophilia is roughly proportional to the degree of shrinkage of cells. Foam-like cytoplasm demonstrates the premortal enlargement of mitochondria:-See Table 4 for biochemical analysis. $\times 1100$. the degradation of nuclear DNA obviously makes it impossible to estimate the quantity per average cell of any protoplasmic constituents to be studied, by taking DNA content as the relative measure of the cell number. Accordingly, in this study, the exotoxin was administered to mice in a high dose so as to kill them in a relatively short period of illness. This seems to have prevented 
the necrotic change from developing in our animals. They showed a subtypical premortal enlargement of mitochondria, which was localized in the outer half of the hepatic lobule. Lower doses might have made the illness of the animal less acute and have afforded sufficient time for the over-all and even development of enlarged mitochondria, but simultaneously, it might well have caused the necrotic change of liver cells.

It could now be postulated that a typical picture of the enlargement of mitochondria can be observed only when the damage of the liver is not so severe to cause the necrotic or fatty degeneration of the liver parenchyma but is sufficiently sluggish to bring about the gradual collapse of animals which leads to the fatal death. In this connextion, it is noteworthy that Annau et al. (1951) described enlarged mitochondria in hypertrophied livers of tumor-bearing mice. In this case however, mitochondria were lacking in many degenerating cells. This type of mitochondrial enlargement may be "non-premortal"

Diffierent pathological changes of the liver which result in a premortal enlargement of mitochondria may have something in common in the metabolic disturbances of the liver which they cause. But the question of whether such an alteration of the hepatic metabolism is the actual cause of the death of animals or whether such a change in mitochondrial size and shape is one of the results of injuries which takes place in cases of the death of this type remains to be answered.

Evidence has been presented before (Sibatani, 1951) that the premortal enlargement of mitochondria has nothing to do with "osmotic" swelling of mitochondria as described by Opie (1948)), Hogeboom, Schneider and Palade (1948), Zollinger (1950), or Harman (1950). In $0.88 \mathrm{M}$ sucrose homogenate, the premortally enlarged mitochondrion retains its large, round shape and staing with Janus green B as a solid, compact body, while a mitochondrion swollen in distilled water loses its stainability with Janus green $B$ and is converted into a non-refractile vesicle occasionally with a small, solid particle or crescent attached to it. Some stainable swollen mitochondria were shown by Opie (1948) in liver slices immersed in distilled water and suggested to be the transitional form. It may be of interest to compare the biochemical activities of premortally enlarged mitochondria with those of the normal ones and of the ones swollen in distilled water.

In previous papers (Sibatani, 1949, 1950) it has been tacitly postulated that the premortal enlargement of hepatic mitochonnria takes place in liver cells the PNA content of which is decreased below a certain threshold value. To test whether this is actually the case, biochemical analyses of nucleic acid and protein were conducted with livers showing premortally enlarged mitochondria. It has thus been revealed that the premortal enlargement of mitochondria may be observed even when there is no significant decrease in PNA per cell of the liver as is the case in the death caused by scurvy, 
though the one caused by prolonged starvation results in diminished PNA per cell and enlarged mitochondria. Obviously, the decrease in PNA content of liver cells per se does not induce the premortal enlargement of mitochondria. It can not be excluded, however, that the decrease in protein per cell is one of the necessary conditions for the appearance of the premortal enlargement of mitochondria.

In addition, it was demonstrated that some of the changes in basophilic pattern of the hepatic cytoplasm are well correlated to the change in concentration of PNA, but they do not necessarily imply the change in PNA content of the cell. The morphologic picture of the liver cell cytoplasm stained with thionin or other basic stains is primarily determined by the size of cells and cell organelles and by the quantity and distribution of cell components other than PNA such as water, proteins, carbohydrates, or lipids. Thus, the conclusion is inescapable that the basophilic pattern of the hepatic cytoplasm may be employed for morphologic recognition of different functional states of liver cells but it should not be interpreted biochemically even as a rough index of PNA content of the cell. Similar conclusions are also reached by Farber et al. (1951) with rat liver showing pathologic changes, by Osawa and Hayashi $(1952,1953)$ with growing newt oocytes, and by Rabinovitch et al. (1952) and by Daly and Mirsky (1952) with mice pancreas.

\section{Acknowledgments}

We express our hearty thanks to Dr. H. Matsuda, Department of Radiology, University of Osaka Medical School, for the facilities in taking the microphotos. Thanks are also due to Dr. J. Y. Homma, Institute for Infectious Diseases, University of Tokyo, for the generous supply of Shigalla dysenteriae exotoxin.

\section{Summary}

Typical pictures of the premortal enlargement of mitochondria were observed in liver of guinea pigs dying from experimental scurvy. Though not typical, similar pictures were also obtained in livers of mice dying from injection of Shigella dysenteriae exotoxin. Pentosenucleic aid (PNA) content of the average liver cell decreased considerably in livers of rats dying of prolonged starvation but remained unchanged in scurvy-dying guinea pig livers, the both cases showing mitochondria typically enlarged. Thus, the decrease in PNA content of the liver cell can not be one of the necessary conditions for the premortal enlargement of hepatic mitochondria. These and additional data on livers with different patterns of cytoplasmic basophilia indicate that the type of basophilia should not be taken as index of PNA content of the liver cell, though it may well be of great morphologic significance. 


\section{References}

Alfert, M. 1952. Biol Bull. 103: 145.

Annau, E., Manginelli, A. and Roth, A. 1951. Cancer Res. 11: 404.

Bourne, G. H. 1951. Cytology and cell physiology, 2. ed., Oxford, 233.

Daly, M. M., and Mirsky, A. E. 1952. J. Gen. Physiol. 36: 243.

Farber, E., Koch-Weser, D., Szanto, P. B., and Popper, H. 1951. Arch. Path. 51: 399.

Fukuda, M., and Sibatani, A. 1953a. Expt. Cell Res. 4: 236.

- 1953b. J. Biochem. 40: 95 .

- 1958c. Experientia 9: 27.

Glick, D., Engstrom, A., and Malmstrom, B. G. 1951. Science 114: 253.

Harman, J. W. 1950. Expt. Cell Res. 1: 394.

Hogeboom, G. H., Schneider, W. C., and Palade, G. E. 1948. J. Biol. Chem. 172: 619.

Homma, J. Y., Katsura, T., Hosoya, S., Miyazaki, Y., Kimura, K., and Saito, N. 1951. Jap. J. Expt. Med. 21 : 381.

Hosoya, S. 1943. Advances in Medicine (Igaku no Sinpo). R. Kinoshita, ed. 1: 88, in Japanese.

Kaufmann, B. P., MeDonald, M., and Gay, H. 1948. Nature 162: 814.

Opie, E. L. 1948. J. Expt. Med. 87: 425.

Osawa, S., and Hayashi, Y. 1952. Science (Japan) 22: 309, in Japanese.

- 1953. Science 118: 84 .

Rabinovitch, M., Rothschild, H. A., and Junqueira, L. C. U. 1952. J. Biol. Chem. 194: 835.

Sibatani, A. 1949. Cytologia 14: 187.

- 1950. Cytologia 16: 58 .

Zollinger, H. U. 1950. Rev. hémat. 5: 696. 